\title{
FAKTOR RISIKO HIPERTENSI PADA ORANG UMUR 45-74 TAHUN DI PULAU SULAWESI
}

\author{
Fatimah Amaliah', Sudikno² \\ 1Program Studi Ilmu Gizi, Fakultas IImu-IImu Kesehatan, Universitas Esa Unggul, Jakarta \\ 2Pusat Teknologi Intervensi Kesehatan Masyarakat, Jakarta \\ fatimahamaliah@ymail.com
}

\begin{abstract}
ABSTRAK
Hipertensi merupakan masalah kesehatan utama baik di negara maju maupun negara berkembang. Tujuan penelitian ini adalah untuk mengetahui faktor risiko yang berhubungan dengan hipertensi pada orang dewasa umur 45-74 tahun di Sulawesi. Penelitian ini menggunakan data Riskesdas 2007. Desain penelitian adalah cross-sectional. Sampel penelitian adalah orang dewasa berumur 45-74 tahun di Sulawesi. Jumlah sampel yang dianalisis 13.859. Hasil penelitian menunjukkan bahwa prevalensi hipertensi ditemukan

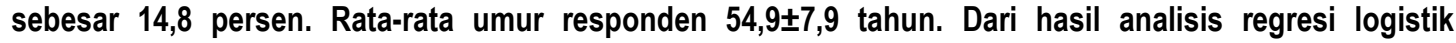
menunjukkan bahwa faktor risiko yang berhubungan dengan hipertensi adalah umur, jenis kelamin, pekerjaan, dan status ekonomi. Pada penelitian ini belum dapat membuktikan adanya hubungan antara kebiasaan makan, aktivitas fisik dengan hipertensi. Program pencegahan terhadap hipertensi perlu dilakukan terutama yang tinggal di perkotaan yang penuh stres dan dengan pekerjaan yang lebih komplek. Disamping itu perbaikan sosial ekonomi dapat merubah gaya hidup seseorang, termasuk dalam makanan dan aktifitas fisik. Disarankan untuk mengurangi konsumsi makanan berisiko (makanan berlemak, jeroan, makanan diawetkan, makanan berpenyedap), dan peningkatan aktivitas fisik secara teratur setiap hari.
\end{abstract}

Kata kunci: faktor risiko, hipertensi, status sosial ekonomi

\section{ABSTRACT}

\section{RISK FACTORS OF HYPERTENSION IN PEOPLE AGED 45-74 YEARS IN SULAWESI}

Hypertension is a major health problem in both the developed and developing countries. The objective of this study was to identify risk factors associated with hypertension in adults aged 45-74 years in Sulawesi. This study uses data Riskesdas (Baseline Health Research) 2007. The study design was cross-sectional. Samples were adults aged 45-74 years in Sulawesi. The number of samples analyzed 13,859. The results showed that the prevalence of hypertension was found to be 14.8 percent. The result showed that the average age of the respondents were $54.9 \pm 7.9$ years. The logistic regression analysis showed that the risk factors associated with hypertension were age, gender, occupation/works, and economic status. In this study, it has not been proved yet a link between eating habits, physical activity with hypertension. However, prevention programs for hypertension needs to be done especially in urban area where people live in stress and with the more complex works . In addition, improvement in socio-economy status may lead to change in life style including meals and physical activity. It is suggested, people should reduce eating risk foods (fatty foods, offal, preserved foods, spicy food), and do physical activity regularly every day.

Keywords: risk factors, hypertension, socio-economy status

\section{PENDAHULUAN}

$\mathrm{H}$ ipertensi hingga saat ini masih menjadi permasalahan utama di bidang kesehatan, tidak hanya di Indonesia namun juga di seluruh dunia. WHO memperkirakan sekitar 80 persen kenaikan kasus hipertensi akan terjadi pada tahun 2025, terutama di negara berkembang, sehingga pada tahun 2025 penderita hipertensi di dunia akan menjadi 1,15 milyar. Prediksi ini didasarkan pada angka penderita hipertensi dan pertambahan penduduk saat ini. ${ }^{1}$

Di Indonesia masalah hipertensi cenderung meningkat. Hasil Survei Kesehatan Rumah Tangga (SKRT) tahun 2001 menunjukkan bahwa 8,3 persen penduduk menderita hipertensi dan meningkat menjadi 27,5 persen pada tahun 2004.,3 Hipertensi menduduki urutan ketujuh dari sepuluh penyakit terbanyak 
rawat jalan rumah sakit di Indonesia dan menduduki urutan keenam rawat inap rumah sakit di Indonesia. ${ }^{4}$

Menurut Lovastatin (2006) menyatakan bahwa konsumsi makanan memberikan kontribusi terbesar terhadap kejadian hipertensi, utamanya makanan berisiko. Makanan berisiko adalah makanan yang dapat menimbulkan resiko penyakit degeneratif. Makanan yang menjadi pencetus timbulnya hipertensi adalah makanan manis, asin, penyedap, makanan yang diawetkan, berlemak, jeroan, dan berkafein (Lovastatin, 2006). Konsumsi lemak dan jeroan dapat memicu terjadinya hipertensi.hal tersebut karena adanya kandungan lemak jenuh (kolesterol). ${ }^{5}$

Selanjutnya Riyadi dkk. (2007) menyatakan bahwa salah satu faktor yang memicu timbulmya penyakit hipertensi adalah ketidak seimbangan antara jumlah asupan zat gizi yang diperlukan dan yang dikeluarkan sehingga menyebabkan status gizi yang tidak seimbang. Kelebihan gizi yang dimulai pada usia 45 tahun ke atas biasanya berhubungan dengan kemakmuran dan gaya hidup. Dengan kondisi ekonomi yang membaik dan tersedianya berbagai makanan siap saji yang enak, nikmat dan kaya akan energy terutama sumber lemak dan karbohidrat, maka terjadi asupan makanan dan zat gizi yang melebihi kebutuhan tubuh. Keadaan kelebihan gizi ini akan membawa pada keadaan obesitas. Perubahan status gizi yang ditandai dengan peningkatan berat badan dapat secara langsung mempengaruhi perubahan tekanan darah. ${ }^{6}$

Prevalensi penyakit hipertensi di Pulau Sulawesi cukup tinggi karena melebihi prevalensi nasional yaitu $(32,3 \%)$. Hal inilah yang melatarbelakangi Penulis untuk menganalisis faktor risiko kejadian hipertensi di Pulau Sulawesi pada kelompok usia 45-74 tahun. Tujuan penelitian untuk mengetahui faktor risiko hipertensi di Sulawesi pada umur 45-74 tahun menurut Riskesdas 2007.

\section{METODE PENELITIAN}

Desain Riskesdas 2007 adalah potong lintang dan merupakan penelitian non-intervensi di 440 kabupaten/ kota di 33 provinsi. Populasi sampel mewakili seluruh rumah tangga di Indonesia. Pemilihan sampel dilakukan secara random dalam dua tahap. Tahap pertama melakukan pemilihan Blok Sensus (BS) dan tahap kedua pemilihan 25 rumah tangga setiap BS. Besar sampel yang dikumpulkan sebanyak 17.165 BS, dengan 258.366 sampel rumah tangga di 33 provinsi. ${ }^{7}$

Data yang dikumpulkan dalam Riskesdas 2007 meliputi keterangan rumah tangga, karakteristik individu anggota rumah tangga, pengukuran berat dan tinggi badan. Pada tulisan ini tidak semua data rumahtangga, individu, dan pengukuran yang diambil untuk dianalisis, tetapi hanya data yang relevan tentang faktor risiko hipertensi di Sulawesi pada orang dewasa berumur 45-74 tahun.

Kriteria data yang diolah dalam analisis tulisan ini adalah sampel individu berumur 4574 tahun di Pulau Sulawesi (umur, jenis kelamin, pekerjaan, pendidikan, status sosial ekonomi, berat badan, tinggi badan), aktivitas fisik, kebiasaan makan (makanan berlemak, makanan jeroan, makanan diawetkan, makanan berpenyedap), diagnosis hipertensi oleh tenaga kesehatan pada 12 bulan yang lalu (ya atau tidak). Pulau Sulawesi merupakan wilayah yang memiliki prevalensi hipertensi yang cukup tinggi (prevalensi hipertensi umur 18 tahun ke atas di Provinsi Sulawesi Tengah dan Sulawesi Barat di atas rata-rata nasional)

\section{Pengolahan dan Analisis Data}

Tahapan analisis data terdiri atas analisis univariat, bivariat, dan multivariat. Analisis univariat dilakukan untuk memperoleh gambaran distribusi frekuensi dan proporsi dari berbagai variabel yang diteliti. Analisis bivariat dilakukan untuk memperoleh ada tidaknya hubungan antara variabel bebas dan terikat dengan menggunakan uji Chi-Square dan regresi logistik, serta uji t-test.

Variabel bebas yang diuji adalah variabel umur, jenis kelamin, status perkawinan, pendidikan, pekerjaan, status ekonomi, aktivitas fisik, kebiasaan makan (makanan berlemak, makanan jeroan, makanan diawetkan, makanan berpenyedap). Sedangkan variabel terikat adalah diagnosis hipertensi tenaga kesehatan pada 12 bulan yang lalu (ya atau tidak).

Pengaktegorian variable tingkat pendidikan meliputi tinggi (SMA ke atas) dan rendah (SMP ke bawah). Status pekerjaan dikategorikan bekerja dan tidak bekerja. Status ekonomi dikategorikan menengah ke atas (kuintil 3, 4,5) dan menengah ke bawah (kuintil 1 dan kuintil 
2). Aktivitas fisik dikategorikan menjadi tiga, yaitu ringan, sedang, dan berat. Indeks massa tubuh (IMT) dikategorikan menjadi lima, yaitu sangat kurus, kurus, normal, gemuk, dan sangat gemuk. Kebiasaan makan (makanan berlemak, makanan jeroan, makanan diawetkan, makanan berpenyedap) dikategorikan menjadi tidak pernah, jarang, dan sering.

Analisis multivariat dilakukan dengan menggunakan analisis regresi logistik yang bertujuan untuk mengetahui besar pengaruh variabel bebas terhadap variabel terikat. Variabel-variabel dengan nilai signifikan $p<0,25$ dipilih, kemudian dimasukkan dalam kandidat model multivariat. Analisis ini menggunakan model binary logistic regression dengan metode enter.

\section{HASIL}

\section{Karakteristik responden}

Jumlah sampel total untuk seluruh Pulau Sulawesi (kecuali Provinsi Gorontalo) sebanyak 13.589 orang. Prevalensi hipertensi (diagnosis oleh tenaga kesehatan) didapatkan sebesar 14,8 persen. Umur rata-rata responden $54,9 \pm 7,9$ tahun. Secara rinci karakteristik responden disajikan pada Tabel 1.

Tabel 1

Karakteristik Responden

\begin{tabular}{|c|c|c|c|}
\hline Karakteristik responden & & $n$ & $\%$ \\
\hline \multirow[t]{2}{*}{ Jenis kelamin } & - Laki-laki & 5764 & 41,6 \\
\hline & - Perempuan & 8095 & 58,4 \\
\hline \multirow[t]{2}{*}{ Tingkat pendidikan } & - Rendah & 10364 & 74,8 \\
\hline & - Tinggi & 3495 & 25,2 \\
\hline \multirow[t]{2}{*}{ Status pekerjaan } & - Bekerja & 8304 & 59,9 \\
\hline & - Tidak bekerja & 5555 & 40,1 \\
\hline \multirow[t]{2}{*}{ Status ekonomi } & - Menengah ke atas & 8627 & 62,2 \\
\hline & - Menengah ke bawah & 5232 & 37,8 \\
\hline \multirow[t]{3}{*}{ Aktivitas fisik } & - Berat & 580 & 4,2 \\
\hline & - Sedang & 2289 & 16,5 \\
\hline & - Ringan & 10990 & 79,3 \\
\hline \multirow[t]{5}{*}{ Indeks massa tubuh } & - Sangat kurus & 288 & 2,1 \\
\hline & - Kurus & 942 & 6,8 \\
\hline & - Normal & 9117 & 65,8 \\
\hline & - Gemuk & 1460 & 10,5 \\
\hline & - Sangat gemuk & 2052 & 14,8 \\
\hline \multirow[t]{3}{*}{ Makanan berlemak } & - Tidak pernah & 2545 & 18,4 \\
\hline & - Jarang & 10549 & 76,1 \\
\hline & - Sering & 765 & 5,5 \\
\hline \multirow[t]{3}{*}{ Makanan jeroan } & - Tidak pernah & 8257 & 59,6 \\
\hline & - Jarang & 5451 & 39,3 \\
\hline & - Sering & 151 & 1,1 \\
\hline \multirow[t]{3}{*}{ Makanan diawetkan } & - Tidak pernah & 5928 & 42,8 \\
\hline & - Jarang & 7421 & 53,5 \\
\hline & - Sering & 510 & 3,7 \\
\hline \multirow[t]{3}{*}{ Makanan berpenyedap } & - Tidak pernah & 826 & 5,9 \\
\hline & - Jarang & 1756 & 12,7 \\
\hline & - Sering & 11277 & 81,4 \\
\hline Total & & 13859 & 100,0 \\
\hline
\end{tabular}




\section{Analisis bivariat}

Berdasarkan Tabel 2 menunjukkan ratarata umur responden yang menderita hipertensi dengan yang tidak menderita hipertensi berbeda. Responden yang menderita hipertensi cenderung memiliki rata-rata umur lebih tua yaitu 56,80 tahun dibandingkan dengan responden yang tidak menderita hipertensi yaitu
54,65 tahun. Uji t-test membuktikan bahwa $\mathrm{p}$ sebesar $0,000 \quad(<0,05)$, hal ini menunjukkan bahwa ada perbedaan yang signifikan antara responden yang menderita hipertensi dengan yang tidak hipertensi menurut umur responden. Selanjutnya distribusi hipertensi menurut karakteristik responden dapat dilihat pada Tabel 3.

Tabel 2

Distribusi Kejadian Hipertensi menurut Umur Responden

\begin{tabular}{|c|c|c|c|c|c|}
\hline \multirow[t]{2}{*}{ Hipertensi } & \multicolumn{3}{|c|}{ Umur } & \multirow[t]{2}{*}{$\mathrm{t}$} & \multirow[t]{2}{*}{$p$} \\
\hline & Mean & $\mathrm{n}$ & SD & & \\
\hline $\mathrm{Ya}$ & 56,80 & 2056 & 8,235 & 11,329 & 0,000 \\
\hline Tidak & 54,65 & 11803 & 7,870 & & \\
\hline
\end{tabular}

Tabel 3

Distribusi Kejadian Hipertensi menurut Karakteristik Responden

\begin{tabular}{|c|c|c|c|c|c|c|c|}
\hline \multirow{3}{*}{\multicolumn{2}{|c|}{ Karakteristik Responden }} & \multicolumn{4}{|c|}{ Kejadian hipertensi } & \multirow{3}{*}{$\begin{array}{c}\text { OR } \\
95 \% \mathrm{Cl}\end{array}$} & \multirow{3}{*}{$p$} \\
\hline & & \multicolumn{2}{|c|}{$\mathrm{Ya}$} & \multicolumn{2}{|c|}{ Tidak } & & \\
\hline & & $\mathrm{n}$ & $\%$ & $\mathrm{n}$ & $\%$ & & \\
\hline \multirow[t]{2}{*}{ Jenis kelamin } & - Laki-laki & 683 & 11,8 & 5081 & 88,2 & 1,51 & 0,000 \\
\hline & - Perempuan & 1373 & 17,0 & 6722 & 83,0 & $(1,37-1,67)$ & \\
\hline \multirow{2}{*}{$\begin{array}{l}\text { Tingkat } \\
\text { pendidikan }\end{array}$} & - Rendah & 1547 & 14,9 & 8817 & 85,1 & 1,02 & 0,602 \\
\hline & - Tinggi & 509 & 14,6 & 2986 & 85,4 & $(0,92-1,14)$ & \\
\hline \multirow{2}{*}{$\begin{array}{l}\text { Status } \\
\text { pekerjaan }\end{array}$} & - Bekerja & 986 & 11,9 & 7318 & 88,1 & 1,77 & 0,000 \\
\hline & - Tidak bekerja & 1070 & 19,3 & 4485 & 80,7 & $(1,61-1,94)$ & \\
\hline \multirow{2}{*}{$\begin{array}{l}\text { Status } \\
\text { ekonomi }\end{array}$} & - Menengah ke atas & 1378 & 16,0 & 7249 & 84,0 & 1,27 & 0,000 \\
\hline & - Menengah ke bawah & 678 & 13,0 & 4554 & 87,0 & $(1,15-1,41)$ & \\
\hline & - Berat & 51 & 8,8 & 529 & 91,2 & - & \\
\hline \multirow{2}{*}{ fisik } & - Sedang & 383 & 16,7 & 1906 & 83,3 & $2,08(1,53-2,83)$ & 0,000 \\
\hline & - Ringan & 1622 & 14,8 & 9363 & 85,2 & $1,79(1,34-2,40)$ & 0,000 \\
\hline Indeks & - Sangat kurus & 31 & 10,8 & 257 & 89,2 & - & \\
\hline \multirow{4}{*}{ massa tubuh } & - Kurus & 111 & 11,8 & 831 & 88,2 & $1,10(0,72-1,68)$ & 0,636 \\
\hline & - Normal & 1252 & 13,7 & 7865 & 86,3 & $1,32(0,90$ & 0,150 \\
\hline & - Gemuk & 258 & 17,7 & 1202 & 82,3 & $77(1,1$ & 0,004 \\
\hline & - Sangat gemuk & 404 & 19,7 & 1648 & 80,3 & $2,03(1,37-$ & 0,000 \\
\hline \multirow{3}{*}{$\begin{array}{l}\text { Makanan } \\
\text { berlemak }\end{array}$} & - Tidak pernah & 433 & 17,0 & 2112 & 83,0 & - & \\
\hline & - Jarang & 1508 & 14,3 & 9041 & 85,7 & $0,81(0,72$ & 0,001 \\
\hline & - Sering & 115 & 15,0 & 650 & 85,0 & $0,86(0,69$ & 0,196 \\
\hline \multirow{3}{*}{$\begin{array}{l}\text { Makanan } \\
\text { jeroan }\end{array}$} & - Tidak pernah & 1315 & 15,9 & 6942 & 84,1 & & \\
\hline & - Jarang & 715 & 13,1 & 4736 & 86,9 & $0,79(0,72-0,87)$ & 0,000 \\
\hline & - Sering & 26 & 17,2 & 125 & 82,8 & $1,09(0,71-1,68)$ & 0,667 \\
\hline \multirow{3}{*}{$\begin{array}{l}\text { Makanan } \\
\text { diawetkan }\end{array}$} & - Tidak pernah & 938 & 15,8 & 4990 & 84,2 & - & \\
\hline & - Jarang & 1057 & 14,2 & 6364 & 85,8 & $0,88(0,80-0,97)$ & 0,011 \\
\hline & - Sering & 61 & 12,0 & 449 & 88,0 & $0,72(0,54-0,95)$ & 0,021 \\
\hline \multirow{3}{*}{$\begin{array}{l}\text { Makanan } \\
\text { berpenyedap }\end{array}$} & - Tidak pernah & 148 & 17,9 & 678 & 82,1 & - & \\
\hline & - Jarang & 199 & 11,3 & 1557 & 88,7 & $0,58(0,46-0,73)$ & 0,000 \\
\hline & - Sering & 1709 & 15,2 & 9568 & 84,8 & $0,81(0,68-0,98)$ & 0,034 \\
\hline
\end{tabular}


Tabel 5

Model Akhir Faktor Risiko Hipertensi pada Orang Dewasa Umur 45-74 tahun di Sulawesi

\begin{tabular}{lccc}
\hline Variabel & OR & Cl: $95 \%$ & $p$ \\
\hline Umur & 1,02 & $1,02-1,03$ & 0,000 \\
Jenis kelamin & 1,32 & $1,19-1,46$ & 0,000 \\
Status pekerjaan & 1,49 & $1,35-1,65$ & 0,000 \\
Status ekonomi & 1,28 & $1,16-1,42$ & 0,000 \\
\hline
\end{tabular}

\section{Analisis multivariate}

Langkah pemodelan diawali dengan mengikutsertakan semua potential confounder dan effect modifier dan selanjutnya dilakukan eliminasi effect modifier. Tahap pertama mengevaluasi variabel kovariat yang masuk dalam model, yaitu dengan melihat hasil $p$ value dari masing-masing variabel terkait dengan status gizi balita. Dari hasil analisis bivariate diketahui bahwa variable (umur, jenis kelamin, status pekerjaan, status ekonomi, aktivitas fisik, kebiasaan makan makanan berlemak, makanan jeroan, makanan diawetkan, makanan berpenyedap) memenuhi persyaratan dalam analisis multivariate ( $p$ value $<0,25$ ). Hasil analisis regresi logistik faktor risiko hipertensi dapat dilihat pada Tabel 4.

Dari pemodelan akhir tersebut di atas dapat dijelaskan bahwa faktor risiko hipertensi pada orang dewasa umur 45-74 tahun di Sulawesi adalah umur, jenis kelamin, status pekerjaan, dan status ekonomi. Dari variabel umur diketahui bahwa setiap peningkatan umur responden mempunyai odds ratio peningkatan risiko hipertensi sebesar 1,02 kali $(1,02-1,03)$. Menurut jenis kelamin diketahui bahwa perempuan mempunyai odds rasio sebesar 1,32 kali $(1,19-1,46)$ untuk mengalami hipertensi dibandingkan laki-laki. Kemudian menurut pekerjaan diketahui bahwa responden yang tidak bekerja mempunyai odds rasio sebesar 1,49 kali $(1,35-1,65)$ untuk mengalami hipertensi dibandingkan responden yang bekerja. Sedangkan menurut status ekonomi diketahui bahwa responden dengan status ekonomi menengah ke atas (kuintil 3,4,5) mempunyai odds rasio sebesar 1,28 kali $(1,16-1,42)$ untuk mengalami hipertensi dibandingkan responden dengan status ekonomi menengah ke bawah (kuintil 1 dan kuintil 2).

\section{BAHASAN}

Tekanan darah Tinggi atau hipertensi merupakan suatu keadaan dimana tekanan darah seseorang adalah $\geq 140 \mathrm{mmHg}$ (tekanan sistolik) dan atau $\geq 90 \mathrm{mmHg}$ (tekanan diastolik). ${ }^{8}$ Hipertensi juga didefinisikan sebagai peningkatan tekanan darah arteri yang dihasilkan dari dua faktor utama yaitu jantung yang memompa dengan kuat dan arteriol yang sempit sehingga darah mengalir menggunakan tekanan untuk melawan dinding pembuluh darah. Kedua faktor tersebut dapat berdiri sendiri atau merupakan gabungan keduanya. ${ }^{9}$

Hasil penelitian ini menunjukkan bahwa faktor risiko yang berhubungan dengan hipertensi pada orang dewasa umur 45-74 tahun di Sulawesi adalah umur, jenis kelamin, status pekerjaan, dan status ekonomi.

Black dan Hawks (2005) menyatakan bahwa seseorang rentan mengalami hipertensi seiring dengan meningkatnya umur. Peningkatan kejadian hipertensi diawali pada umur 20 tahun. ${ }^{10}$

Hasil ini sejalan dengan penelititian Tesyafe et al., (2007) menyatakan bahwa ada hubungan antara jenis kelamin dengan kejadian hipertensi. Dalam penelitiannya juga didapatkan hasil yang menunjukkan prevalensi hipertensi pada wanita lebih besar dibaningkan laki-laki. Hal ini terjadi karena adanya pengaruh genetik dan umur. ${ }^{11}$

Menurut MN. Bustan (1997) bahwa wanita lebih banyak yang menderita hipertensi dibandingkan pria, hal ini disebabkan karena terdapat hormone estrogen pada wanita. ${ }^{12}$ Hormon estrogen ini kadarnya akan semakin menurun setelah menopause. ${ }^{13}$

Menurut Setiawan (2006) bahwa laki-laki lebih berisiko menderita hipertensi daripada 
wanita. Hal tersebut terjadi karena perilaku tidak sehat (merokok dan konsumsi alkohol), stress dan status pekerjaannya. ${ }^{13}$ Penelitian Rahajeng (2009) juga mendapatkan risiko laki-laki terkena hipertensi 1,25 kali lebih tinggi daripada wanita. ${ }^{15}$

Walaupun dalam penelitian ini belum dapat membuktikan hubungan antara kebiasaan makan makanan berisiko (makanan berlemak, makanan jeroan, makanan diawetkan, makanan berpenyedap) dan aktifitas fisik dengan hipertensi, namun beberapa studi telah membuktikan adanya hubungan tersebut. Penelitian Chataut et al. (2011) pada 527 subyek berumur 18 tahun ke atas di Nepal menunjukkan bahwa faktor risiko terkait dengan hipertensi adalah umur, jenis kelamin, pendidikan, aktivitas fisik, indeks massa tubuh, merokok, dan perilaku merokok. ${ }^{16}$ Penelitian sebelumnya menunjukkan adanya hubungan antara aktivitas fisik yang kurang dengan hipertensi. .77, $18,19^{1}$

Untuk mencegah kejadian hipertensi Joint National Committee on Prevention, Detection, Evaluation, and Treatment of High Blood Pressure (JNC7) merekomendasikan modifikasi gaya hidup. Program penurunan berat badan, mengurangi sodium dalam makanan, aktifitas fisik secara teratur minimal 30 menit hampir setiap hari, mengonsumsi banyak sayuran dan buah-buahan, mengonsumsi produk susu rendah lemak. ${ }^{20}$

Huang et al. (2008) merekomendasikan tentang perilaku makan sehat, mengurangi sodium dalam makanan, mengurangi asupan alkohol, dan aktivitas fisik secara teratur untuk mencapai berat badan yang ideal dalam rangka menurunkan hipertensi. ${ }^{20}$

\section{SIMPULAN DAN SARAN}

\section{Simpulan}

Prevalensi hipertensi pada orang dewasa umur 45-74 tahun di Sulawesi sebesar 14,4 persen. Faktor risiko yang berhubungan dengan hipertensi adalah umur, jenis kelamin, pekerjaan, dan status ekonomi. Pada penelitian ini belum dapat membuktikan adanya hubungan antara kebiasaan makan, aktivitas fisik dengan hipertensi.

\section{Saran}

Perlu dilakukan penelitian yang lebih mendalam terkait dengan faktor risiko hipertensi dengan desain penelitian yang berbeda. Program pencegahan terhadap hipertensi perlu dilakukan sejak usia dini, dengan mengurangi konsumsi makanan berisiko (makanan berlemak, makanan jeroan, makanan diawetkan, makanan berpenyedap), dan peningkatan aktivitas fisik secara teratur setiap hari.

\section{UCAPAN TERIMA KASIH}

Terima kasih diucapkan kepada Kepala Badan Penelitian dan Pengembangan Kesehatan Kementerian Kesehatan RI atas penggunaan data Riskesdas 2007.

\section{RUJUKAN}

1. Depkes Rl. Pedoman Surveilans Penyakit Jantung dan Pembuluh Darah. Jakarta: Departemen Kesehatan Republik Indonesia, 2008

2. Departemen Kesehatan RI. Survei Kesehatan Rumah Tangga. Jakarta: Badan Litbangkes, 2001

3. Departemen Kesehatan Rl. Survei Kesehatan Rumah Tangga. Jakarta: Badan Litbangkes, 2004.

4. Departemen Kesehatan RI. Profil Kesehatan Indonesia 2009. Jakarta: Depkes RI, 2010.

5. Lovastatin K. Penyakit Jantung dan Tekanan Darah Tinggi (Pengenalan gejala, Pencegahan dan Penanganan dengan Metode Alami). Jakarta: Prestasi Pustaka Publisher, 2006.

6. Riyadi A, Wiyono P, Budiningsari DR. Asupan Gizi dan Status Gizi Sebagai Faktor Risiko Hipertensi Esensial Pada Lansia di Puskesmas Curup dan Puskesmas Perumnas Kabupaten Rejang Lebong Propinsi Bengkulu. Jurnal Gizi Klinik 2007;4(1): 43-51.

7. Departemen Kesehatan RI. Laporan Riskesdas tahun 2007. Jakarta: Badan litbangkes, 2008.

8. Chobanian AV, Bakris GL,Black HR. The Seventh Report of the Joint National 
Committee on Prevention, Detection, Evaluation, and Treatment of High Blood Pressure. JAMA 2003; 289:2560-2571.

9. Simon W. What is Blood Pressure?, Cambridge: Harvard Medical School, 2002.

10. Black JM, Hawk JH. Medical surgical nursing: clinical management for positive outcomes. $7^{\text {th }}$ edition. St.Louis: Elsevier Saunders, 2005.

11. Tesfaye $F$, Nawi NG , Minh HV ,Byass $P$, Berhane $Y$, Bonita R, S Wall. Association Between Body Mass Index and Blood Pressure Across Three Population in Africa and Asia. Journal of Human Hypertension 2007; 21: 28-37.

12. Bustan MN. Epidemiologi Penyakit Tidak Menular. Jakarta: Rineka Cipta, 1997.

13. Armilawaty. Hipertensi dan Faktor Risikonya Dalam Kajian Epidemiologi. Thesis. Makasar: Universitas Hasanudin, 2007.

14. Setiawan Z. Karakteristik sosiodemografi sebagai faktor resiko hipertensi studi ekologi di pulau Jawa tahun 2004. Tesis. Jakarta: Universitas Indonesia, 2006

15. Ekowati R, Tuminah, Sulistyowati. Prevalensi Hipertensi dan Determinannya di Indonesia. Jakarta: Depkes, 2009.
16. Chataut J, Adhikari RK, Sinha NP. Prevalence and Risk Factors for Hypertension in Adults Living in Central Development Region of Nepal. Univ Med J.2011; 33(1):13-8.

17. Das SK, Sanyal K, Basu A. Study of urban community survey in India: growing trend of high prevalence of hypertension in a developing country. Int J Med Sci. 2005; 2(2): 70-78

18. Sharma AK, Bhardwaj $S$, Chaturvedi $S$. Predictors of Hypertension in an Urban Indian Population. Indian Heart J 2006; 58 : 21-27.

19. Shanthirani CS, Pradeepa R, Deepa R, Premlatha G, Saroja R. Prevalence and Risk Factors of Hypertension in a Selected South Indian Population - The Chennai Urban Population Study. JAPI.2003;51(Januari):20-27.

20. National Institutes of Health. Blood Pressure Education Program: Implementing recommendations for dietary salt reduction. Chicago: NIH Publication, 2003.

21. Huang H, Duggan K, Harman J. Lifestyle management of hypertension. Australian Prescriber. 2008;31(6):150-153. 